\title{
The Russian Language in Soviet Russia in the 1920-30-s
}

\author{
Svetlana Sorokin \\ National Research University Higher School of Economics, Moscow \\ Corresponding author: lana40ina@mail.ru \\ Olga Musorina \\ Candidate of Science, History; \\ Penza University of Architecture and Construction
}

\section{Doi:10.5901/jesr.2013.v3n7p112}

\begin{abstract}
The present inquiry addresses the problem of functional, stylistic and other changes in the Russian language in postrevolutionary Russia. This phenomenon known as "the Soviet language" is argued to have been a specific tool in building the new Soviet state with all its political, cultural and educational institutions. The research is based on comparative analysis method. The authors analyze the aims and results of the Soviet government policies applied to the state key institutions as well as the interdependence and interaction between the Soviet ideology and the language transformation. The investigation touches upon the historic background of political, economic and cultural changes after the Russian revolution of 1917. The main channels of ideological intervention are proved to have been school education, mass (proletarian) culture, mass media, penetration into the everyday life of the Soviet people. The findings reveal that the Soviet Russian language developed into one of the main Soviet propaganda tools due to the wide use of abbreviations, place names and clichés that turned it into a crucial factor in establishing "the right thinking" of the Soviet citizens.
\end{abstract}

Keywords: language change, the Soviet language, abbreviations, slogans, clichés

\section{Introduction}

\subsection{Research Background}

There is an opinion that the process of civilization development is represented by a succession of the so-called languages paradigms of mankind social progress resulting in the establishing of the language view of the modern society evolution (Gorelikov,L.A \&\& Lisitsina,T.A.,1999). The contemporary world picture is described as a product of AngloSaxon language community. The 15-17 centuries were marked by the French dominance. The process of historical evolution influences any language and is influenced by it. During the Soviet period in the Russian history the Russian language was considered to be a means of communication between the people living in the Soviet Union and could have been seen as a competitor (rival) to the English language as the world language. The development of Stalin's government model in Russia including all its social institutions and symbols remains one of the key issues in foreign and Russian historical studies. The main aspect of the research is the transformation of the Russian peasantry into a new social community - the so called Soviet people (Kozlova, 1995).In 1920-30-s the process of transformation took place under the influence of economic, cultural and educational factors. The process of social adaptation to the new historical situation became possible due to measures and government policies in the sphere of language development. This phenomenon came to be known as the Soviet language. The Soviet language can be termed the "language of the epoch" to describe dialectical integrity of verbal and non-verbal symbols that provide the semantic unity of a society.

During the period described the world witnessed the spread of the American variant of the English language and the existence of the Nazi variant of the German language.

Therefore the political history of the XX century can be understood through studying and analyzing language development process in those countries that underwent dramatic political, economic and as a result cultural changes at the period. Such techniques, methods and tools of ideological impact as propaganda, agitation, public relations, advertising got their wide application and were based on linguistic methods and approaches. 
The importance of the study is determined by the following considerations:

i. In the period of the world transition to the global economy and information society it seems to be important to analyze and evaluate the XX century experience and heritage not only in the field of economy but in such spheres as education, culture as well as non-economic instruments and tools implemented by governments to build the desired view of the world.

ii. To fully understand the Soviet heritage in the development of contemporary Russia it is useful to take into consideration the fact that cultural and behavior models of several generations of Russian citizens are deeply rooted in cognitive structures and concepts of the Soviet language.

\subsection{Purpose and objectives of the study}

The purpose was to investigate the process of the Russian language change in the 1920-30-s taking into account such language function as exerting the influence (Keller, 1994). The study was guided by the following objectives:

1. To reveal the main channels of language change;

2. To analyze the key means and tools of language change.

\subsection{Hypotheses}

The following hypotheses were put forward and analyzed:

i. The Soviet Power made a successful use of different channels, means and tools of language development to impose the Soviet model of state by constructing a new view of the world.

ii. The process and results of language change and development were similar throughout the territory of the country.

\section{Methodology}

The research into the process of language change in post-revolutionary Russia carried out by numerous Western, Soviet and Russian researchers has been observed and analyzed.

The study is based on the comparative analysis of processes and data of different levels and periods. In addition the functional approach is used to evaluate the process of language change through its functioning. To provide interdisciplinary approach the study is conducted at the nexus of two fields of science: history and linguistics.

German linguist Rudi Keller (1994) identifies the main function of a language as that of exerting influence to others. In our research we apply his theory to the explanation of processes and phenomena in language change.

The main sources of the study are:

1. Documents published in collections of archival papers,

2. Documents of the 1920-30-s from Penza regional branch of the State Archive of the Russian Federation,

3. Newspapers dated the 1920-30-s (The Trudovaya Pravda, The Stalinskoie Znamya).

\section{Material Review}

S. Fitzpatrick $(1999,2008)$ focuses on the social and cultural history of the Stalinist period. Analyzing various aspects of social identity and daily life she touches upon the problems of education, cultural revolution, social mobility. Much attention is paid by the historian to the change of cultural paradigm of the society including the change of personal names and place names.

D. J. Raleigh (2001) suggests the idea that the discourse of Bolsheviks included two party languages - external (the language of Bolshevik newspapers, public meetings and agitation literature) and internal (that of secret reports and documents). He asserts that a party member could use either "external" or "internal" language depending on the environment.

R. Pipes $(1986,1997)$ explores Bolsheviks ` policies in the sphere of religion and culture and gives examples of language change.

M. Geller $(1982,1983)$ has coined the term "the Soviet language" and constructed its conception.

The Nazi variant of the German language was described by V. Klemperer in his book "Lingua Tertii Imperii"( the Russian edition in 1998). 
N. Kozlova (1995) analyzes the diaries of Communist party members and comes to the conclusion that the Soviet language was used by everyone: those who supported the Soviet Power and those who disagreed with it. She also reveals that some ordinary members of the party used this language not only in public, but in private.

A. Besancon $(1986,1998)$ analyses the compromise of two languages within the Soviet language - the party language and the people`s language.

\section{Discussion}

Changes in the language that led to the establishment of the Soviet language prove to have been prompted by the following social and economic conditions: change of the social class structure and migration of the population, industrialization, collectivization, low level of general culture and education (Fitzpatrick, 1999, 2001).

According to the official statistics, before $191780 \%$ of Russian population were peasants. Russia was an agricultural country characterized by high level of industrial production concentration and well organized revolutionary working class. N. Kozlova (1995) writes that by the end of the 1920-s Russian peasants bore the title of "the disappearing class" and anticipated dramatic changes in their lives. According to N. Kozlova, the process of adaptation went through such social institutions and structures as the army, Komsomol ( the Young Communist League), education, moving from the country to town. She points out that there were two levels of adaptation:

- obtaining a new identity by going through all social and political filters;

- reaching the top of the social hierarchy, coming to power.

The starting point for these two levels had to be the imitation of new forms of social behavior and public speaking.

That is why it is important to mention main channel and methods of language impact (manipulation). The authors consider the following channels as the leading ones in the process:

- educational institutions (schools, vocational training courses, institutes) including the system of political education;

- mass culture;

- mass media;

- ideologization of daily life, penetration to a person`s private life.

One of the primary tasks of the Soviet government was the elimination of illiteracy as in $185593 \%$ and in 1897 about $77 \%$ of Russian population were illiterate. Geller (2000) points out a close interdependence between the level of literacy and the process of urbanization. Thus, given the high rate of industrial development in Russia at the beginning of the XX century the percentage of literate people started to grow. In the Soviet times the elimination of illiteracy in postrevolutionary Russia was considered to be one of the main achievements of the Soviet state. But it can also be seen as a world-wide tendency that Bolsheviks took advantage of. However, the real purpose of the Soviet power was not only to teach the illiterate people reading and writing but to teach them "the right thinking". V.Lenin (1918) wrote in his works that "An illiterate person is out of politics and therefore has to learn the alphabet. Without it there cannot be any politics." In May 1924 there appeared a society called "Get rid of illiteracy!". By the end of the 1920-s in Penza region, for example, there were 745 points organizing the teaching process for a total number of 12-14 thousand learners. Nevertheless, the rate was slow and the results were modest until the introduction of compulsory primary and secondary education for children and teenagers. The ideological approach to all spheres of education, science and culture had the aim to construct proletarian (Soviet) vision of the world that was in the root of each curriculum, any field of science and technology. It should be stressed that the word "Soviet" became a keyword in the Soviet language entering a lot of wordcombinations: the Soviet people, the Soviet government, the Soviet way of life.

Mass media were supposed to be an effective means of ideological treatment of the population. After October revolution all oppositional newspapers were closed because of a different interpretation of events.

The language function of exerting influence found its realization in such trends and approaches as:

- stylistic changes that came in the accordance with the Soviet government policies.

- society stratification and social hierarchy.

- naming facts of everyday life, private communication.

- geographical names.

The study showed that the most widely used linguistic tools became clichés, slogans, repetition, choice of words to describe the reality as well as political labeling. Most clichés were taken from the works or speeches of Soviet political leaders V.Lenin and J.Stalin. One of them was "engineers of human souls" - i.e. Soviet writers. The most terrible phrase was without any doubt "a people's enemy" coined by V.Lenin in 1917 to call his political rivals and opponents. Ten years 
later, in 1927 Stalin used this phrase regarding L.Trotsky and some other political figures of that period. It began to regularly appear in Soviet newspapers and on the radio. Soon this cliché turned into a legal term.

The most popular slogans of the period described included Lenin's or Stalin's quotes: "Life turned to better, life turned to happier". ILife became better, life became happier.

"Everything depends upon the staff".

"Everything depends upon the technique"

Political labeling included such words as "kulak"(a wealthy peasant). "lishenets" (person having no civil rights), "vreditel" (i.e. saboteur - someone who purposively does harm to the state property). People bearing such labels were subject to legal prosecution. In modern Russian such words remain as historical terms.

It should be stressed that the period of the 1920-30-s became a period of place names changes. The key event in that process was marked by acquiring another official name for the country - the Soviet Union. (It is interesting to note that the word "Russia" was not politically used until the 1990-s). In 1924 after the death of V.Lenin the former Russian capital Petrograd changed its name to Leningrad. Some towns, located in the Volga area were renamed in honour of Bolshevik political leaders. The town of Simbirsk (a birth place of Vladimir Lenin, the leader of 1917 October Revolution and the Soviet State) was named Ulianovsk (Ulianov was the real surname of V. Lenin). Samara was changed to Kuibyshev, Tsaritsin-on-Volga became Stalingrad (Fitzpatrick, 1999). The process of place name changes affected other regions of the country: Perm (in the Ural regions) became Molotov, Vladikavkaz (in the Caucasus region) became Ordzhonikidze. It is interesting to note that in 1920 the names of I. Stalin and V. Lenin were not among leaders in renaming. But later, after V. Lenin's death in 1924 and at the period of political repression when lots of leaders and ordinary members of the Bolshevik movement were sent to prison or executed, some cities and towns were returned their original names (e. g. Perm).

Not only cities and towns had the names of outstanding political figures. Their names were given to factories, collective farms, cinemas and theatres, streets. The central Moscow street - Tverskaya - was called Gorky street in honour of the "great proletarian writer" Maksim Gorky (Peshkov). Another famous street- Myasnitskaya - was turned to Kirov Street, Bolshaya Lubianka - to Dzerzhinsky Street (both were prominent political figures of the Bolshevik movement).

Outside Moscow the process of changing place names was going practically in every city, town or village. According to the research conducted in the provincial town of Penza in the 1980-s, the large-scale renaming brought to life a lot of new street names to commemorate heroic lives, deeds and often deaths of outstanding figures of October revolution, writers, pilots, working class representatives that often became legendary figures. In the 1930-s members of the flying profession (pilots, test-pilots) became especially popular. In Penza at least nine streets got the names of prominent Soviet aviators: Belyakov, Vodopianov, Gromov. Chkalov, Grizodubova, etc.) (Godin ,1983) There were objective reasons for the process. The period of industrial development in the Soviet Union prompted the growth of cities and towns. Therefore there was a great need for names to be given to new streets. At the same time it marked the beginning of a new life to the people of the country where such names as Lyagushovka (meaning something like "a frog area") or Kozlovka ( "a goat area") were not only outdate but politically wrong.

An integral part of many names and titles used to be the word "krasnylkrasnaya" ("of red colour"). We can find this word in the place names, e.g. Krasnaya Polyana (Red Meadow), Krasnopolie (Red Field), Krasny Kut or in the names of state and collective farms, factories and plants: Krasnaya Niva, Krasny kolkhoznik (Red collective farmer). The example demonstrates that the word lost its original meaning: in Soviet Russia and Soviet Union "krasnylkrasnaya" meant a true revolutionary, a person devoted to the ideals of the revolution. Alongside with that tendency there was another one: some names associated with Russian history or stuck deep in the Russian patriarchal conscience failed to be changed. Take, for example, Moscow, the capital of the country. If there had been attempts to rename it, they would have been in vain. When the local authorities in Penza tried to rename the central street in the town from Moskovskaya (Moscow street) into Kommunisticheskaya ( Communizm street) the citizens rejected the new name and the old one was returned to the street.

Personal names and surnames also were subject to changes. At first they were connected with revolution and scientific progress ( Fitzpatrick,1999): Iskra (i.e. "spark" - from the name of the first Bolshevik newspaper), Barrikada (i.e. "barricade") , Edison, Electron, Kim (an abbreviation from "Communist Youth International"). Some were derivatives from the name of Vladimir Lenin, e.g. Vladlen. But it didn't lead to a new tradition. People often refused to give such names to their children because they came in conflict with Russian cultural traditions and stereotypes. The authors found only two cases of having revolutionary names. In Penza there lived and worked a talented composer Oktyabr Grishin (born in 1918, Oktyabr means October). And one woman of the same age had the name of Stalina. 
Abbreviations came to be a productive means of vocabulary enlargement. Initially they were intended to identify lots of new notions including political parties, government agencies, public organizations, etc. It should be stressed that abbreviations became widely spread in many European languages in the 19th century due to political developments, one of them being formation in European countries such government systems that depended on political parties. Another reason was widely spread development of education when literacy of common people became a common thing. Numerous industries were creating new jobs and working places. All that led to changes in languages: in their lexical and grammatical structure.

In the 1890-s with the beginning of the so-called proletarian stage in the Russian revolutionary movement the language got such abbreviations as РСДРП \ RSDRP - Russian social-democratic labour party: ЦК \TsK - Central Committee and others. They were used by members of revolutionary movement. In the field of industry there were such words as "prodmet"- sale of metals. During World War I there appeared words like "glavkoyuz" - commander-in-chief on the south-western front. After October 1917 there was a strong tendency to shorten word combinations, to use abbreviations in many spheres of life and in every language style including private communication. In the preface to the 1-st edition of "Political Dictionary" (1922) it was written that "The revolution , turning and destroying in its development all ideas and concepts, ... revealed a need for a new...scientific political dictionary that would satisfy the newly-born reader...who is no more a "Russian inhabitant...but a free citizen of the Russian Federative Socialist Republic."( translated by us - S.Sorokina, O.Musorina). Examples of the most widely used abbreviations include:

PKПIRKP - Russian Communist party,

PCФCPIRSFSR - Russian Socialist Federative Soviet Republic;

Соввласть|Sovvlast - Soviet powerlauthority;

HЭPINEP - New Economic policy.

In the 1920-s lots of abbreviations were appearing and disappearing because at that period the new Soviet state was establishing itself throughout the country and abroad. Late 1920-s and 1930-s are characterized by the situation when most abbreviations finding their place in political, industrial, social and cultural spheres were widely used and recognized by the citizens of the country. Moreover, they were not subject to further changes and became self-sufficient. In fact they were not emotionally neutral: those who used them felt strong emotions from pride for their native land to fear, uncertainty, even hatred. And after the collapse of the Soviet Union they are considered to be historical terms. Among those are CCCPIUSSR, HKВДINKVD, ОГПУIOGPU, ЦИКI TsIK.etc.

A wide range of abbreviations used in newspapers can be illustrated by an excerpt from one of them. The plan for celebrating the International Cooperation day included at least 27 abbreviations, the total number of words in the abstract being 52. ( Newspaper "The Trudovaya Pravda", 1931,27 July)

As in every form of word-building activity we can find examples of clumsy abbreviations, e.g." chevkolap" - an emergency commission for supplying shoes (so-called "lapti" or "bast shoes") to the army. Such "masterpieces" were criticized by the press in short Russian folk-songs -in "chastushkas".

It is interesting to note that some words changed their meaning or connotation.

The word "worker" began to denote not only a man or women of a working profession, but in most cases a representative of the leading group of population and gave a person great carrier opportunities. As for the word "zabastovka" (rebel, riot), it acquired a negative meaning. Before 1917 "zabastovka" was one of primary forms of working class protest. In the 1920-30-s it turned to be a criminal offence.

It should be stressed that the process of language change in the Soviet period in this or that form continued until the1980-s but the Soviet language as a set of rhetoric codes and rules was established in the period of the 1920-30-s and later was only slightly modified. Many of the words, phrases and definitions of the Soviet period are in great use now, so we can consider the Soviet language to be a part of the modern Russian language.

\section{Conclusions}

i. The investigation of the process of the Russian language change in 1920-30-s taking into account such language function as exerting the influence proved the idea that the use of certain channels, linguistic means and tools can influence people's thinking and behavior.

ii. The main channels of language change such as educational institutions (schools, vocational training courses, institutes) including the system of political education; mass culture; mass media and their role in the ideologization of daily life and penetration to a person`s private life were analyzed.

iii. Considering the leading means and tools of language change it has been revealed that the most common of 
them were such language means as abbreviations, slogans, clichés, change of place names and personal names.

iv. As many of the words, phrases and definitions of the Soviet period are in great use now, we can consider the Soviet language to be a part of the modern Russian language. This can help to better understand Russian policies and cultural model.

\section{Recommendations}

i. We recommend the results of the study be used while analyzing the political history of the XX century.

ii. The provided material might be applicable to such scientific areas as public relations, text interpretation, and political studies as it reveals some methods and tools of ideological impact.

iii. The analysis design can be applied to the investigation of language changes in other historical periods.

iv. The study can help in understanding the political situation in today's Russia as the country has retained a lot of Soviet heritage.

\section{References}

Besancon, A. $(1986,1998)$. The Soviet Present and the Russian Past. Paris, Moscow.

Geller, M.\& Nekrich, A.(2000). Utopia at Power. Moscow.

Godin, V.S.(1983) Streets of Penza. Penza.

Gorelikov, L.A \&\& Lisitsina, T.A.(1999). The Russian Path. Ethnic and Linguistic Philosophy Experience. Parts 1-3, Veliky Novgorod.

Fitzpatrick, S. (1999, 2001). Everyday Stalinism: Ordinary Life in Extraordinary Times: Soviet Russia in 1930-s. Oxford University Press.

Keller, R. (1994). On Language Change. The invisible hand in language. Routledge.

Klemperer, V. (1998). Lingua Tertii Imperii. Moscow.

Kozlova, N.(1995). Hostages of the Word. Sotsiologicheskie issledovaniya, No. 9-10.

Society and Power. 1930-s. A Narration in Documents (1998), Moscow.

Lenin, V.(1986). Collection of works. Moscow, Vol. 33 p. 55

Pipes, R. (1999, ) Russia Under the Bolshevik Regime. United States. Vintage Books.

Political Dictionary.(1922). Moscow.

Raleigh, D.J.(1986). Revolution on the Volga: 1917 in Saratov. Cornell University Press.

Raleigh, D.J. (2002). Experiencing Russia's Civil War: Politics, Society and Revolutionary Culture in Saratov, 1917-1922. Princeton University Press.

Raleigh, D.J. (2001). To Speak as a Bolshevik or How Saratov Bolsheviks Described Their Enemies. Otechestvennaya Istoria ,\#5.

The Trudovaya Pravda. Newspaper (1931, 27 July) 